\title{
Modeling human agency in land change in Madagascar: A review and prospectus
}

\author{
William J. McConnell'
}

\begin{abstract}
Preserving Earth's biodiversity is one of the central challenges to global sustainability, and the task is complicated in developing countries by the need to avoid further compromising the ability of resource-dependent people to secure their livelihoods. The challenge is all the more daunting given the scarcity of resources available to the effort, necessitating reliable analyses of the role of human agency and the effects of various policy prescriptions. New sources of data and computational tools available to researchers over the past two decades have enabled the development of quantitative models of human agency in land change, including a special class known as spatially explicit models. This article explores advances in understanding human agency in land change in Madagascar in order to synthesize lessons learned and identify remaining challenges. It concentrates on the findings of a number of recent spatially explicit modeling efforts, identifying progress in accounting for human presence in the landscape. Other quantitative and qualitative studies point to the importance of a broad array of additional factors, particularly those reflecting interactions among agents. Bringing together the various perspectives on human agency in land change in Madagascar should enable them to better contribute to the formulation of policy that can balance protection of the island's biodiversity with securing the livelihoods of the Malagasy people.
\end{abstract}

\section{RÉSUMÉ}

La conservation de la biodiversité est I'une des pièces maîtresses de l'utilisation pérenne des ressources de la planète et la tâche est d'autant plus complexe dans les pays en voie de développement dans lesquels les moyens de subsistance des populations rurales sont étroitement liés à leur capacité d'accéder aux ressources naturelles. La tâche est aussi ardue que les ressources financières disponibles sont limitées, de sorte qu'il est important de bien comprendre comment s'articule I'organisation humaine autour des politiques et programmes de conservation mis en œuvre (l'expression 'organisation humaine' qui traduit 'human agency' est employée ici pour désigner les activités physiques des hommes - comme les défrichements pour cultiver le riz - mais englobe aussi des dimensions éthiques, culturelles et légales qui pourraient être à l'origine de l'absence

\author{
Center for Systems Integration \& Sustainability \\ Michigan State University, Suite 115, Manly Miles Building1405, \\ South Harrison Road, East Lansing, MI 48823-5243, U.S.A. \\ Phone: +1 517-432-7108 \\ E-mail: mcconn64@msu.edu
}

d'action - comme la menace de répressions du défrichement pour la culture du riz-étant entendu que l'organisation s'entend au niveau individuel mais aussi collectif en pouvant résulter d'une action ayant un impact réel sur le paysage ou de l'absence d'une telle action.) Grâce à de nouvelles sources d'informations mais aussi de nouveaux outils et procédés informatiques développés au cours des vingt dernières années, il a été possible d'élaborer des modèles quantitatifs portant sur l'organisation humaine dans les dynamiques des paysages en incluant une catégorie particulière dénommée 'spatially explicit', à savoir un modèle explicitement spatial. Cet article aborde les progrès réalisés pour mieux appréhender I'organisation humaine dans la dynamique des paysages à Madagascar, récapitule l'apprentissage en la matière et formule les nouveaux défis à relever dans ce domaine.

Il apparaît clairement que pour comprendre le rôle de I'organisation humaine dans la dynamique des paysages, il faut commencer par aborder la présence et la distribution des gens dans l'espace. Les modèles existants ont nettement mis en relation la 'pression démographique' et la déforestation anthropique et cela depuis les travaux de Green et Sussman publiés en 1990. Cependant, les conclusions tranchées de l'époque ne sont pas aussi fiables qu'elles prétendaient l'être et plus particulièrement en ce qui concerne la relation de cause à effet entre la croissance démographique et les défrichements, de sorte que nous présentons quelques recommandations méthodologiques inspirées d'autres approches analytiques.

Les modèles existants ont confirmé les observations de Green et Sussman (1990) montrant un taux de défrichement réduit dans les régions à topographie accidentée mais ont aussi dévoilé l'importance d'un certain nombre d'autres facteurs tels que les infrastructures de transport, les différences d'accès des communautés rurales aux moyens de production, la sécurisation foncière et d'autres actions du gouvernement ou d'organisations non gouvernementales.

Au fur et à mesure que les modélisations rendent mieux compte du rôle de tels facteurs, elles devraient alors permettre d'évaluer plus précisément la pertinence des efforts déployés pour protéger la biodiversité. Cet aspect peut être envisagé avec un certain espoir bien que de manière préliminaire ; la conversion des forêts à des usages agricoles dans les aires protégées semble être réduite par rapport à cette même dynamique 


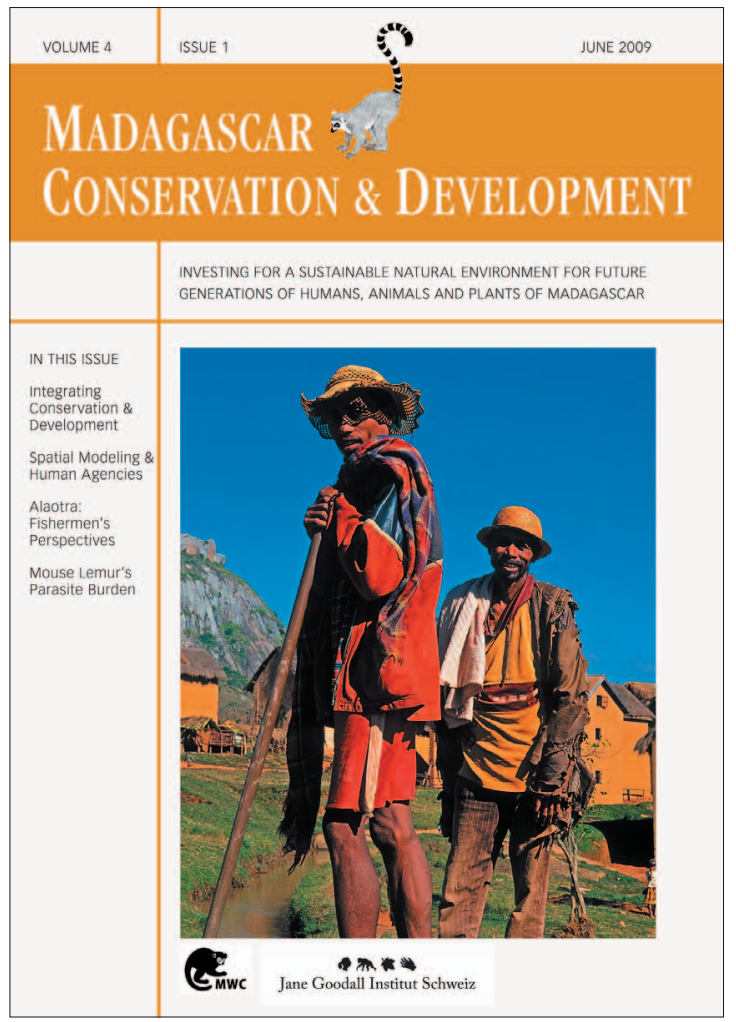

Madagascar Conservation \& Development is the journal of Madagascar Wildlife Conservation (MWC) and the Jane Goodall Institute (JGI Switzerland). It is produced in these institutions' own responsibility.

All the Issues and articles are freely available at http://www.mwc-info.net/en/services/journal.htm

Contact Journal MCD

info@journalmcd.net for general inquiries MCD funding@journalmcd.net for supporting the journal

Journal Madagascar Conservation \& Development Institute and Museum of Anthropology University of Zurich

Winterthurerstrasse 190

$\mathrm{CH}-8057$ Zurich, Switzerland

contact@mwc-info.net for general inquiries

Postfach 2701

CH-8021 Zürich, Switzerland

Logement 11, Cité Andohaniato Antananarivo 101, Madagascar

info@janegoodall.ch for general inquiries JGI

$2 \pi \approx$

Jane Goodall Institut Schweiz
Jane Goodall Institute Schweiz

Postfach 2807

8033 Zürich

Switzerland 
observée dans des aires comparables mais non protégées. Ces conclusions devraient être étayées au fur et à mesure que les modélisations seront en mesure d'intégrer d'autres facteurs dont l'importance sera révélée par diverses études scientifiques et qui portent aussi bien sur les contextes environnementaux que sur les interactions au sein des communautés humaines L'intégration de ces diverses perspectives analytiques devraient permettre aux modélisations de contribuer à élaborer une politique pertinente pour protéger au mieux la précieuse biodiversité de l'île tout en assurant les moyens de subsistance des populations rurales de Madagascar.

KEYWORDS: Madagascar, conservation, land-use, spatially explicit model, human agency.

MOTS CLEF : Madagascar, protection de la nature, utilisation des terres, modèle explicitement spatial, organisation humaine.

\section{INTRODUCTION}

In 2003, the biodiversity conservation community was pleased to hear Madagascar's President, Marc Ravalomanana, outline a bold, new initiative to increase protection of the island's imperiled biodiversity. In what became known as the 'Durban Vision,' he pledged before the World Parks Congress that his government would triple the size of the country's network of protected areas by 2008 (Norris 2006). As this deadline approached, the government also began negotiating a 99-year lease with Daewoo Logistics for production of maize and oil palm destined for South Korea (Walt 2008). Together, these two policies directly concern about $10 \%$ of the island's land area, and more than half of its arable land, making it more important than ever to accurately understand threats to biodiversity and the consequences of protection efforts.

The stakes in this endeavor are high: Much of the flora and fauna being targeted for protection are found nowhere else on Earth, but the financial resources available for conservation are quite scarce, and their efficacious use requires the application of state-of-the-art scientific methods (Ferraro and Pattanayak 2006). On the other hand, the act of protecting biodiversity requires a major shift of land-use rights away from some of the world's poorest farmers.

In response to the need to understand land-use dynamics in Madagascar, a number of models have recently been developed that aim to quantify the role of human agency in altering the island's landscapes (Table 1). These quantitative models form a new branch of a literature whose roots can be traced as far back as the work of Etienne de Flacourt in the middle of the $17^{\text {th }}$ century. This literature blossomed in the early $20^{\text {th }}$ century with the study of the island's natural history (a review can be found in Andriamialisoa and Langrand 2003). Scholarship on the human imprint on the island flourished in rich geographical and anthropological case studies of land-use in many parts of the island in the latter half of the century by, for example, Blanc-Pamard and Cambrézy (1995), Coulaud (1973), Kottak (1980), Kull (1998), Le Bourdiec (1974), Raison (1970), and Rakoto Ramiarantsoa (1995).

While those studies did involve the collection and analysis of quantitative information, several studies in the past decade have taken the additional step of developing quantitative models that specify mathematical relationships between land-use (the manifestation of human agency on the land) and a range of social and biophysical factors, using means such as regression analysis. The advantages of quantifying these relationships include the possibility of parsing the relative contributions of causal and contextual factors and the estimation of a degree of confidence in the assessment of those relationships. Thus, in principle, the recently developed quantitative models are more useful than earlier studies for the design and evaluation of policies and programs concerning land-use. Whether this is true is a central question of this review. One approach - spatially explicit modeling - has gained wide currency across disciplines, particularly within the integrative field of land-change science (Gutman et al. 2004, Turner II et al. 2007). The term refers to a class of models in which explaining the behavior of the system in question depends on consideration of the spatial relationships among variables (Kaimowitz and Angelsen 1998, Mladenoff and Baker 1999, Skole and Cochrane 2004, Walker and Solecki 2004). In the case of spatially explicit regression, the algorithms applied are no different from those applied elsewhere, rather it is the explicitly spatial nature of the input variables, and sometimes the spatial interpretation of the results, that distinguishes this approach.

The approach enables the consideration of landscape variables, such as land cover and its underlying topography, which can often be made available at relatively high spatial resolution. As a result, large numbers of observations can be used in 'natural experiments' that isolate the effect of certain variables of interest, particularly those resulting from government policies and programs, on an outcome, like deforestation. In effect, locations subjected to a localized treatment - such as the construction of a road, or land-use restrictions - can be compared with 'control' locations that were similar in other important respects. However, the need to obtain geo-referenced data at appropriate spatial scales for each variable constitutes a significant, costly constraint to the development of such models, and it is important to evaluate how robust the results are and the degree to which the benefits of developing the models are worth the cost.

This article reviews the practice of modeling human agency in land change in Madagascar in order to synthesize the lessons learned and identify remaining challenges. Examples of spatially explicit models are examined and compared to other types of land-use studies to identify common directions and opportunities for cross-learning. It is important to note that this review draws almost exclusively on the peer-reviewed literature easily accessible to scholars outside of Madagascar. A great deal of very important work has been conducted outside of this domain by Malagasy and other scholars. The paper concludes with a set of recommendations for future models of land change in Madagascar.

\section{SPATIALLY EXPLICIT LAND-USE MODELS: ORIGINS AND ACCOMPLISHMENTS}

In 1990, a landmark study was published in Science, bringing satellite remote sensing to bear on the longstanding question of the role of human agency in land change in Madagascar. Green and Sussman (1990) developed maps of the island's humid eastern rainforests from satellite images, which they compared to maps developed three decades earlier.

The resulting map of forest-cover change was then crosstabulated with maps of population density and topography. The 
TABLE 1. Spatial, temporal and thematic characteristics of the main studies reviewed

*IGN/FTM topographic maps S-47N and S-47S (PERINET and LAKATO), based on aerial photographs from 1957, scale: 1:50,000. L'Institut Géographique

National (France)/Foiben-Taosarintanin'l Madagasikara (Madagascar). ** Both studies cite the use of 100-meter, vertically-spaced contour data, the contour interval used in the FTM's 1:500,000 map series. Reference information for the sources not provided in the published work. *** FTM publishes a very popular 1:500,000 maps series, as well as a 1:1,000,000 series, but not a 1:1,500,000 as described in note 29 in Green and Sussman (1990).

\begin{tabular}{|c|c|c|c|c|c|c|c|}
\hline & \multirow{2}{*}{$\begin{array}{l}\text { Spatial Extent } \\
\left(\mathrm{km}^{2}\right)\end{array}$} & \multirow{2}{*}{$\begin{array}{l}\text { Spatial } \\
\text { Resolution } \\
\text { (ha) }\end{array}$} & \multirow{2}{*}{$\begin{array}{l}\text { Temporal } \\
\text { Extent } \\
\text { (years) }\end{array}$} & \multicolumn{2}{|c|}{ Population } & \multicolumn{2}{|c|}{ Topographic } \\
\hline & & & & Variables & Data Source & Variables & Data Source \\
\hline $\begin{array}{l}\text { Gorenflo et al. } \\
\text { (In press) }\end{array}$ & 587,000 & 1,000 & $1990-2000$ & $\begin{array}{l}\text { density at firaisana } \\
\text { level }\end{array}$ & $\begin{array}{l}1993 \text { census, } \\
\text { INSTAT }\end{array}$ & elevation, slope & $\begin{array}{l}\text { 1:500,000 } \\
\text { topographic maps, } \\
\text { FTM }^{* *}\end{array}$ \\
\hline $\begin{array}{l}\text { Green and Sussman } \\
\text { (1990) }\end{array}$ & $\sim 200,000$ & 81 & $1950-1985$ & $\begin{array}{l}\text { density at canton } \\
\text { level }\end{array}$ & 1966 census, AGM & slope & $\begin{array}{l}1: 1,500,000 \\
\text { topographic maps, } \\
\text { FTM }^{* \star *}\end{array}$ \\
\hline $\begin{array}{l}\text { Agarwal et al. } \\
(2005)\end{array}$ & 75,000 & 100 & 1993 & $\begin{array}{l}\text { density at firaisana } \\
\text { level }\end{array}$ & $\begin{array}{l}1993 \text { census, } \\
\text { INSTAT }\end{array}$ & elevation, slope & $\begin{array}{l}\text { 1:500,000 } \\
\text { topographic maps, } \\
\text { FTM }^{* *}\end{array}$ \\
\hline $\begin{array}{l}\text { McConnell et al. } \\
\text { (2005) }\end{array}$ & 940 & 0.09 & $1957-2000$ & $\begin{array}{l}\text { settlement dis- } \\
\text { tance, with and } \\
\text { without distance } \\
\text { decay }\end{array}$ & $\begin{array}{l}\text { 1:50,000 topo- } \\
\text { graphic maps, FTM* }\end{array}$ & elevation, slope & $\begin{array}{l}\text { 1:50,000 } \\
\text { topographic maps, } \\
\text { FTM* }^{*}\end{array}$ \\
\hline Vågen et al. (2006) & 476 & 0.09 & $1957-2003$ & $\begin{array}{l}\text { density and settle- } \\
\text { ment distance }\end{array}$ & $\begin{array}{l}\text { African Population } \\
\text { Database, "existing } \\
\text { maps" }\end{array}$ & elevation, slope & $\begin{array}{l}\text { 90m Shuttle } \\
\text { Radar Topography } \\
\text { Mission, NASA JPL }\end{array}$ \\
\hline
\end{tabular}

study's main finding of more rapid rates of forest clearance in areas of higher population density has been widely cited in academic publications and in the popular press. The study has also been regularly referred to in policy documents of the country's major donors, such as the United States Agency for International Development, which embraced the paper's recommendation for rapid action to conserve the remaining forest.

Green and Sussman's work (1990) provided no measure of the strength of the relationship between forest-cover change and population density or slope and, therefore, was not a model of human agency. However, numerous efforts have been made to test its conclusions in more rigorous quantitative fashion, including three spatially explicit regression models on subsets of the Green and Sussman study area (Agarwal et al. 2005, McConnell et al. 2004, Vågen 2006) and another for the island as a whole (Gorenflo et al. In press) (see Figure 1, Table 1).

All four studies were able to detect statistically significant relationships between deforestation and variables measuring human population distribution, showing the fundamental population-deforestation relationship to be robust. Green and Sussman's (1990) other main finding was that forest had disproportionately been cleared on flatter land at lower elevations. McConnell et al. (2004), Agarwal et al. (2005), and Vågen (2006) confirmed this relationship as well, with elevation usually exhibiting a slightly weaker relationship with deforestation than population, and slope providing even less explanation.

Confirming the Green and Sussman (1990) findings, however, was not the goal of these spatially explicit models. Rather, they set out to account for the role of these factors so that they could then detect the effects of other factors, particularly those susceptible to public policy. Three of the studies (Agarwal et al. 2005, Vågen 2006, Gorenflo et al. In press) demonstrated that where government has furnished transportation infrastructure, nearby forests were more likely to be felled. The studies also showed that deforestation is muted in wealthier areas and in areas with greater internal disparity of income (Gorenflo et al. In press), and accentuated (i) where soils are poor (Gorenflo et al. In press), (ii) when migrants failed to secure legal access to land (McConnell and Sweeney 2005), and (iii) during periods of political instability (Vågen 2006).

of particular interest here, the spatially explicit models have begun to deliver on the promise of providing evidence of the effectiveness of biodiversity conservation efforts. Both McConnell et al. (2004) and Gorenflo et al. (In press) were able to provide initial evidence that deforestation rates in protected areas were lower than in comparable nearby areas. These studies have advanced our understanding of the causes of

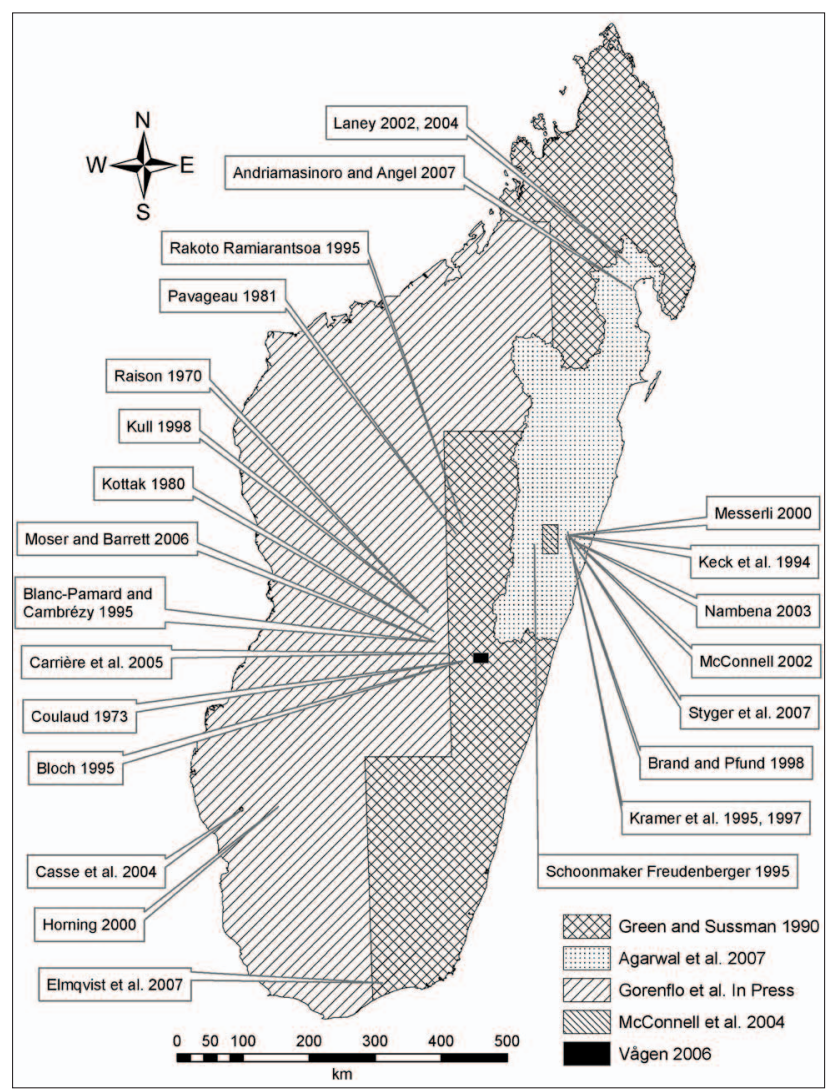

FIGURE 1. Locations of studies mentioned in the text with conterminous study areas. 
deforestation, but their results are far from perfect and answer only half of the question. While they tell us that conservation efforts have been able to reduce the loss of forest, many of the relationships they detected are barely statistically significant, leaving considerable room for improvement. Furthermore, they tell us little or nothing about the welfare effects of conservation efforts on the rural populations most directly affected. Fortunately, many other studies of land-use in Madagascar provide valuable lessons for addressing the shortcomings of spatially explicit land-use models (see Figure 1). The bulk of this article constitutes a critical examination of the ways that the spatially explicit studies have treated the factors thought to influence land-use. It employs a broad categorization of factors, following meta-analyses of tropical deforestation (Geist and Lambin 2002, Rudel 2005), agricultural change (Keys and McConnell 2005), and desertification (Geist and Lambin 2004).

This review concentrates on three major categories of factors: Demographic, including the distribution and dynamics of human population in the landscape; socioeconomic, including access to productive resources and the role of local and state institutions; and biophysical, such as landform, soil quality, and climatic factors. Each section begins with a critical review of the approaches taken in the spatially explicit models and then turns to other studies for theoretical and methodological enrichment. Further, these other studies are mined for their attention to the ways that local production systems adapt to the closing of agricultural frontiers, and thus address the consequences of conservation efforts for local people, which are crucial to the sustainability of conservation policies. For the sake of brevity, the studies' depictions of the dependent variable - deforestation - are taken as valid, although there is reason to question their reliability. These issues are discussed in more detail elsewhere (Nelson and Horning 1993, McConnell 2001).

\section{DEMOGRAPHIC FACTORS: POPULATION 'PRESSURE'}

The most common factor analyzed in land-change studies is a set of variables meant to represent the pressure local populations, especially resource-dependent people, exert on the nearby landscape (Lambin and Geist 2006). This category encompasses a broad range of processes, such as fertility, settlement patterns, and various forms of migration, but due to the need to amass data amenable to computation, the spatially explicit models have tended to employ fairly crude measures. It is important to examine the studies' methods carefully in order to understand the reliability of their findings, particularly with respect to the representation of population density, and the degree to which they account for spatiotemporal dynamics, and therefore the justification for their causal claims about the relationship between population dynamics and land-use.

POPULATION DENSITY The simplest way to represent

human agency in the landscape is to map the spatial distribution of people at some point in time. This is typically done with a population density map that assigns a value to areal units, generally persons $/ \mathrm{km}^{2}$. The source of population data for the Green and Sussman (1990) study was a map published in the Atlas de Madagascar (Association des Géographes de Madagascar 1969), showing population density by canton (an older colonial small administrative division similar to a district). The data, collected in 1966, were presented in the Atlas in five popu- lation-density classes, including one showing areas with more than 100 persons $/ \mathrm{km}^{2}$, yet Green and Sussman (1990) chose to collapse the three highest-density classes into a single class of more than 10 persons $/ \mathrm{km}^{2}$. This simplification bears scrutiny.

The island's total land area is approximately $587,000 \mathrm{~km}^{2}$, and it had a total population of approximately 12 million people during the study period. Thus, average population density on the island would have been nearly 20 persons $/ \mathrm{km}^{2}$ and urban densities were likely several times higher. With no rainforest remaining near the country's most densely populated areas (e.g. Antananarivo), the higher density regions (i.e. $>50 / \mathrm{km}^{2}$ ) were areas in which the deforestation ratewasnil, by definition. Including these higher density classes in their study would have led to a very different conclusion about the relationship between population and land-use.

Subsequent, spatially explicit studies employed a variety of approaches to depicting population pressure, although they used continuous variables, thereby avoiding the categorical simplification described above. The broader-scale studies (Agarwal et al. 2005, Gorenflo et al. In press) used similar source maps depicting population density at the firaisana level (similar to the canton/district level data used by Green and Sussman) derived from the census published in 1993. The population variable in the former study was population count, subjected to a rather complex interpolation to a raster grid that does not correspond to a traditional density value. The latter study employed a sampling approach in which values for population density at nearly 100,000 point locations within firaisana polygons were paired with forest cover in satellite image pixels. Meanwhile, the two finer-scale studies on portions of the eastern rainforest edge (McConnell et al. 2004, Vågen 2006) used proximity to village settlements to represent population 'pressure' on nearby forest. In addition to simple Euclidean distance, the former developed more complex surfaces from Voronoi tesselation around village centroids and gravity (potential interaction) models using various distance decay exponents. None of these more complex surfaces produced a stronger relationship with deforestation than simple distance from village centers.

The fact that the four studies all found correlations between their measures of deforestation and population density provides some degree of support for Green and Sussman's (1990) conclusion. However, other studies of deforestation in Madagascar have found mixed results on the association between population density and deforestation rates. For example, a study in the southern dry forests found a non-linear relationship between forest dynamics and a population density variable derived from the LandScan 2001 Global Population Database (Elmqvist et al. 2007). Among four study areas analyzed, the most dramatic loss of forest occurred in a moderately populated area, while forest cover remained stable in the most densely populated areas.

Not all studies of land-use in Madagascar have been concerned solely with deforestation. Many have addressed land-use dynamics when forestland available for conversion to agriculture becomes limited, leading to changes in production systems. There is a substantial body of literature on the conditions under which agricultural production shifts from expansive forms, such as swidden (tavy), to more sedentary forms involving greater technology, such as plows or irrigation. One of the foundational works in this vein was Esther Boserup's (1965) work focusing on land pressure as the key to understanding agricul- 
tural growth (Chowdhury and Turner II 2006). While the spatially explicit models in Madagascar do not directly build on this literature, other studies do, beginning with the work of French geographers in the 1970s (e.g. Raison 1970, Coulaud 1973).

In his treatise on the Zafimaniry in the south-central highlands, Coulaud (1973) referred to Boserup's (1970) work on the issue of fallow land in African production systems. Working in the waning days of manual cartography, Coulaud wrestled with the various ways of representing population density graphically, comparing maps indicating village locations and number of inhabitants with canton-level choropleth and weighted grid density maps that 'spread' the rural population outside the residential cores of the villages. His calculations led him to conclude that population density in portions of the Pays Zafimaniry surpassed 50 persons $/ \mathrm{km}^{2}$.

Laney $(2002,2004)$ likewise draws upon this literature in her study of land-use in the Andapa region. She calculates effective population density, based only on land claimed by community members, in order to characterize trajectories of agricultural change. This approach yielded population density in one village of 135 people $/ \mathrm{km}^{2}$. It is noteworthy that in the three spatially explicit models that provided information on population density in persons per km² (Agarwal et al. 2005, Vågen 2006, Gorenflo et al. In press), the densities tended to be rather low compared to the densities calculated in other studies (Coulaud 1973, Keck et al. 1994, Kull 1998, Laney 2002, 2004, Elmqvist et al. 2007).

TEMPORAL DIMENSIONS AND CAUSAL CLAIMS it is one thing to compare a map of land-use with a map of population density and detect a correlation. It is another thing to establish a causal linkage between population growth and deforestation. Unfortunately, the conflation of correlation and causation is an all-too-common problem in land-change studies generally (Kaimowitz 1997, Lambin 2000, Millington et al. 2007).

Having effectively aggregated most of the island's population, including most city dwellers, next to the forest and finding higher rates of deforestation in these more populous areas Green and Sussman (1990: 212) conclude "the major threats to the remaining forest are driven by subsistence needs." This claim is made without evidence of a causal relationship; rather it is substantiated by reference to three non-peer-reviewed sources. The authors apparently assumed that if deforestation is happening close to large numbers of people, then those people must be responsible; and since they are overwhelmingly subsistence farmers, they must be clearing forests. Yet their data contain neither information about population dynamics, nor on the land-use practices of the people in the landscape.

Agarwal et al.'s (2005: 123) model commits a similar - albeit milder - conflation of correlation and causation, stating "Increased population pressure increased the chances of forest degradation." The statement suggests that a change in population was observed to have led to a change in the likelihood of deforestation, when in fact both the population density and forest cover variables represent single points in time, and the analysis simply detected a statistically significant correlation in the form of a spatial coincidence of their patterns; no process was actually observed. The authors do refer to three historical maps to derive suggestions about demographic trends over the past century, but these dynamics did not figure in their regression analysis, due to lack of data. The only spatially explicit model that did include a variable representing population dynamics was Vågen (2006), who tested the relationship between deforestation and change in decadal population density depicted in the coarse-resolution (1- $\mathrm{km}^{2}$ pixel) African Population Database (APD) (Deichmann 1994). However, the spatial interpolation of population distribution in the APD maps is driven by quite coarse proxy variables that are unlikely to capture actual demographic processes at such fine scales. It is not surprising that this variable failed to relate well with observed changes in land cover.

Other land-use studies in Madagascar have addressed this issue more directly, sometimes with contradictory results. In seeking to shift responsibility for deforestation from poor peasants to colonial logging enterprises, Jarosz $(1993,1996)$ drew on a report of the French Institut national d'études démographiques to conclude that much of the destruction of the country's eastern rainforest occurred during a period when population may have been stable or even declining. A case study of forest dynamics in the southwestern part of the country (Casse et al. 2004) was able to detect a positive, albeit weak and indirect, relationship between increase in the number of inhabitants of six villages over a decade and increases in distance between those villages and the nearest available forest. Kull (1998) used district-and canton-level figures from various sources to document strong population growth in a southern highlands study area throughout the $20^{\text {th }}$ century, which he qualitatively related to agricultural expansion depicted in aerial photographs across four decades.

Keck et al. (1994) tackled the agricultural intensification question in an eastern rainforest study region, also drawing on the agricultural change literature (e.g. Boserup 1965, Pingali et al. 1987). They evaluated pressure on the swidden system using the R-value measure of cultivation frequency (Ruthenberg 1976) and concluded "the region is on the verge of evolution to a short fallow farming system" (Keck et al. 1994: 14). They also concluded that the change is associated with population increase, although the source of their estimate of $3.5 \%$ annual population growth is not cited. Laney $(2002,2004)$ likewise focuses on cropping frequency in her differentiation of farms that had modified their production systems in ways that enabled them to maintain or increase levels of consumption from others that followed involution and stagnation trajectories (Geertz 1963).

It is significant that population mobility, or migration, is all but absent from the spatially explicit models reviewed here, despite its important role in many parts of the island over the past century. McConnell et al. (2004) suggest that migration may have accounted for some of the false positive residuals of their logistic regression model of deforestation, but did not attempt to construct a variable to test this hypothesis. Other studies have documented the importance of a variety of processes, including voluntary migration, such as the settlement of the 'Vanilla Triangle' in the northeast after foreign coffee and vanilla producers discovered the region's rich soils (Laney 2002), and cyclical abandonment and recolonization in the south (Elmqvist et al. 2007). In some instances, government encouragement, or even coercion, has led to resettlement, particularly to move populations away from natural forests (Coulaud 1973). Migration continues to shape land-use throughout the island, including rural immigrants driven by land pressure in their home areas to search for agricultural land elsewhere, or for employment in farming, mining, or urban enterprises (Schoonmaker Freudenberger 1995, Durbin et al. 2003, Casse et al. 2004, Kull 2008). 


\section{SOCIOECONOMIC AND INSTITUTIONAL FACTORS}

Once the distribution and dynamics of the population have been accounted for, land-use studies generally turn to a number of interrelated factors that shape land-use practices. These factors range from characteristics thought to shape the behavior of the inhabitants, to the various institutions that constitute the social milieu in which land-use takes place, be they clan or lineage groups, village or other community structures, government agencies, or non-government organizations (Chowdhury and Turner II 2006).

TRANSPORTATION The presence of transportation

infrastructure, particularly roads, is probably the most commonly studied manifestation of government influence in land-change models globally, and deforestation analyses in particular (Nelson and Hellerstein 1997, Kaimowitz and Angelsen 1998, Geist and Lambin 2001, Rudel 2005). Such infrastructure commonly serves as a proxy for the ability of local people to access both land for conversion and / or extraction and technology and information. Three spatially explicit models addressed the role of transport infrastructure in shaping land-use. Vågen (2006) and Gorenflo et al. (In press) detected significant relationships between deforestation and distance from roads and paths digitized from topographic maps published by Foiben-Taosaritanin'i Madagasikara (FTM), Madagascar's mapping agency. Agarwal et al. (2005) developed a simpler binary variable representing presence / absence of transportation routes (footpath, rough track, motorable track, primary road, and railroad) from FTM maps, and likewise found this variable strongly related to deforestation.

None of the spatially explicit models includes a variable representing change in transportation infrastructure, making it difficult to assess causality. The FTM map series depicts the transport infrastructure in its current state to the degree possible, but maps are revised infrequently. Metadata on these revisions are too brief to enable the user to know at exactly what point the roads and paths may have conformed to the representation in any given published map. Little major road development has taken place in Madagascar since 1957, although major upgrades have been made in some locations. Elsewhere, degradation is the norm, with temporary and longer-term interruptions inhibiting physical connections to markets and, more generally, discouraging farmers from risking the investment of scarce resources in cash crop production (Schoonmaker Freudenberger 1995). Such dispersed and intermittent disruptions pose a substantial challenge for modeling.

A further challenge is that in many parts of the country the existence of a road is not a reliable proxy for market demand, since sales of agricultural produce depend on the few people who are able to operate trucks to transport goods from rural areas. One study of deforestation (Casse et al. 2004) oddly ruled out transportation costs as a useful explanatory factor, suggesting that all farmers receive the same farmgate price, although prior work suggests large differentials in prices depending on a farm's location within the precarious road network (Bernier and Dorosh 1993, Karaska et al. 1996, Fafchamps and Minten 2002). New econometric work on the impact of hypothetical new roads has provided a valuable foundation for the empirical treatment of such factors in future land-use models, such as Jacoby and Minten's (2008) canonical model for farmers' willingness to pay for new roads.
SOCIOECONOMIC STATUS For the most part, spatially explicit studies have treated people in the landscape as homogeneous in all respects other than their spatial distribution, failing to take account of their relative access to productive resources. One exception is Gorenflo et al. (In press), who made use of data from The World Bank on consumption-based welfare at the firaisana level (Mistiaen et al. 2002). With this data, they were able to show that deforestation rates tend to be lower in wealthier areas and in areas with greater internal disparity of income.

The relative availability of the resources necessary for farming is traditionally central to agricultural change studies. A series of studies conducted by researchers affiliated with Cornell University in the 1990s on rice production in Madagascar focused on farms' endowments of land, labor, and capital. Bernier and Dorosh (1993) found that household characteristics, such as cattle ownership, and various measures of educational attainment showed strong relationships with fertilizer adoption. This group also analyzed the likely effects of liberalization in rice marketing, finding that while higher prices would spur wealthier farmers to increase production, they penalized the majority of farmers who were producing below subsistence level and had to purchase rice (Barrett and Dorosh 1996).

Subsequent work focused on the adoption of a suite of irrigated rice-growing techniques known as the System of Rice Intensification (SRI). Barrett et al. (2004) used regression models to confirm that better endowed farms, in terms of land and labor, as well as experience and the means to apply manure, derive the greatest benefit from the adoption of SRI. They found that while all farmers stand to benefit from adopting SRI, less well-endowed farmers choose not to because, for them, the variability of SRI production outweighs the potential benefits, creating a strong disincentive.

Later, Moser and Barrett (2006) detected statistically significant relationships between initial SRI adoption and landholdings, especially lowlands suitable for irrigated rice production, and several other measures of 'liquidity' (e.g. off-farm income, reliance on agricultural day labor). They found that the larger, diversified farms producing wheat and dairy products were less likely to suffer from seasonal bottlenecks, enabling them to invest in SRI. Adoption rates were significantly lower among households forced by land shortage to sell their labor to other farms.

LAND TENURE In farming communities, wealth is often closely linked to access to land, either to convert land for agricultural production or to utilize existing cropland. It is therefore no surprise that this issue has figured prominently in landchange studies in Madagascar, although the spatially explicit models have barely begun to address the issue. Mcconnell et al. (2004) found some evidence in their regression residuals to support the previous findings of Schoonmaker Freudenberger (1995), who reported the clandestine clearing of fields inside the Maromizaha forest by residents unable to obtain land through the admixture of customary and state authorities.

Access to land resources in Madagascar is traditionally governed by local customary institutions reflecting the initial settlement of the landscape and the community's subsequent political history (Keck et al. 1994, Schoonmaker Freudenberger 1995, Laney 2002, McConnell 2002, Raik 2007). The French colonial government introduced a system of formal land titling in the early $20^{\text {th }}$ century; however, Keck et al. (1994) found 
only $5 \%$ of the farmers in their study held formal title to their land, and nationally it has been estimated that the rate is less than $10 \%$, leaving the remainder under customary control (Montagne and Bertrand 2006).

The slow pace of the formalization of land rights was long thought by economists at The World Bank and elsewhere to pose a major obstacle to agricultural development in Africa. Case studies in Madagascar, however, have not always supported this thesis. For example, a World Bank study in the area adjacent to the Mantadia National Park (Keck et al. 1994) concluded that lack of access to markets, for both inputs and farm produce, were at least as important as formal land rights in hindering intensification. Likewise Randrianarisoa and Minten (2001) demonstrated that increasing formal land titling is unlikely to have a significant effect on improved agricultural performance in Madagascar, compared to other factors.

Some land-use studies have shown the importance of inter-household interactions regarding access to land. For example, Laney $(2002,2004)$ highlighted the significance of the annual arrangements for borrowing and renting land among families in the Andapa region for differentiating household land-use intensification trajectories. Elsewhere, Kull (1998) highlighted the salience of renting and sharecropping arrangements that have shaped land-use change in the central highlands in past decades. Interestingly, Keck et al. (1994) found these arrangements absent in the eastern rainforest region they studied. Bellemare and Barrett (2003: 14) developed a model of a form of sharecropping found in Madagascar called 'reverse share tenancy' in which poor households rent out land to richer tenants on shares. The authors hypothesize that "as property rights become more secure, reverse tenancy sharecropping will tend to disappear, with poorer land owners benefiting from reduced ... inefficiency as a result of endogenously changing agrarian contracts" and suggest that property-rights enforcement will be important to redress this problem.

STATE AND LOCAL INSTITUTIONS Providing formal title

to land is one way the state intervenes in the question of access to land. No less important, though, is the state's claim to all remaining land. The Malagasy state has asserted exclusive rights to the island's forests since at least the 1800s, and under the French regime these lands were mapped and various levels of protection ascribed, ranging from very strict (e.g. Strict Nature Reserve) to less restrictive (e.g. classified forests). Together, these various forms of state exclusion accounted for about half of the island's 13 million hectares of standing forests by the end of the $20^{\text {th }}$ century (Direction des Eaux et Forêts 1996).

Two spatially explicit models have addressed the success of these protection efforts. McConnell et al. (2004) found some evidence of the success of formal restrictions in maintaining the integrity of core forest blocks in a national park and a special reserve. Gorenflo et al. (In press: 15) were able to derive an actual estimate for the amount of protection afforded: "Other factors held constant, the presence of a protected area will on average decrease the probability of deforestation by $5.2 \%$ per decade. In relative terms this translates into about $61.5 \%$ reduction [sic] below the base deforestation rate for Madagascar as a whole".

The state's claims to land have not gone uncontested by local populations, and Vågen (2006) attributes a period of rapid deforestation in the 1990s to the "turbulent political situa- tion" at that time, as the local population took advantage of lax enforcement (Vågen 2006: 223). Other studies have elaborated similar themes, relating the burning of grasslands and forests in defiance of, or in protest against, state land-use restrictions (Jarosz 1993, 1996, Kull 2004). These actions have sometimes been explained in terms of the desire of rural people to ensure the persistence of cultural value systems. For example, in the highlands, Bloch (1995) showed how highly the Zafimaniry value the creation of 'openness' in landscapes, while Kull (2008) explicates the seemingly counter-intuitive Betsileo notion of 'saving land' by improving it through cultivation. Similar institutional factors relating to production systems have been shown to significantly affect land-use in Madagascar. For example, Bernier and Dorosh (1993: 46) found individual respondents' fertilizer use to be highly correlated with a variable describing the proportion of farmers in the region also using fertilizer. They offer two possible interpretations of this 'neighborhood effect': It may demonstrate intra-communal interaction in "the quality of water control in an irrigated perimeter shared by many farms"; alternatively, it may be related to a government fertilizer promotion program. Subsequent studies found similar factors to be important correlates of land-use: Variables describing social conformity, 'learning effects' (learning from other farmers), membership in farmer organizations, and extension services were all found to be significantly related to the adoption of SRI (Moser and Barrett 2006). Other studies in Madagascar have amply demonstrated the importance of social capital in the form of non-monetized transfers of wealth among farm families (Bernier and Dorosh 1993, Karaska et al. 1996) and information exchange among agricultural food products traders (Fafchamps and Minten 2002).

While the maintenance of local customs offers some explanation of land-use, their deterioration has also been cited. For example, Bloch (1984) showed how increasing pressure on land resources and worsening terms of trade led to the breakdown of cultural institutions such as reciprocal labor exchange, which had been crucial to the construction and maintenance of shared irrigation infrastructure. This erosion of local institutions has been linked to a more general social crisis with land-use implications, including banditism and cattle rustling (Kottak 1980, Pavageau 1981, Bloch 1984). The threat of losing proceeds to theft is a strong disincentive for both livestock production and the production of agricultural surpluses (Vérin 1992, Karaska et al. 1996). Econometric work has begun to pave the way for the incorporation of rural insecurity in land-use models, quantifying the relationship between cattle rustling and other crimes and geographical isolation, as measured by distance from urban centers and low population density (Fafchamps and Moser 2003).

Expansion of the country's protected area network under the Durban Vision and the possible leasing of over a million hectares of land for export farming create a strong need for rigorous analysis of the effectiveness of policy options. The task is all the more complex as the range of forest management regimes has recently expanded to include a range of contractual arrangements with local communities (Antona et al. 2004, Montagne and Bertrand 2006, Raik 2007).

These circumstances may seem to pose an insurmountable level of complexity, but fortunately the literature in commonproperty resources (Ostrom et al. 2002) offers substantial guidance, including sets of 'facilitating conditions' (Wade 1994) 
and 'design principles' (Ostrom 1990) for effective governance of common resources (Agrawal 2002). Several studies of land-use in Madagascar have applied these frameworks in the comparative analysis of forest governance regimes, including Elmqvist et al. (2007) who compared four sites in the southeast, finding the worst conditions in the area with the least coherent enforcement of access rules. Two studies also applied the standardized protocols developed by the International Forestry Resources and Institutions (IFRI) research program (Ostrom and Wertime 2000), including Horning (2000) comparing forests in the southwest and McConnell and Sweeney (2005) comparing forests in the east coast and central highlands. The IFRI approach specifies questions related to the physical aspects of the resource to which access is being managed (the forest), the particular uses for which the forest is managed, the characteristics of the user groups, and the rules that govern those uses. In these studies, forests managed for multiple products through collaboration among user groups to establish and enforce rules were found to be achieving greater success.

\section{BIOPHYSICAL FACTORS}

While it might be expected that biophysical factors would play prominent roles in studies of land-use change, this has not generally been the case globally (Geist and Lambin 2002, 2004, Keys and McConnell 2005). Land-use studies in Madagascar have mainly focused on topography, following Green and Sussman (1990). According to their Science article, their slope map was derived from 1:1,500,000-scale topographic maps published by FTM in 1980, although no other reference to this map series has been located. The subsequent spatially explicit models employed higher precision data sources, such as NASA's Shuttle Radar Topography Mission (SRTM) at 90-m pixel resolution (Vågen 2006) or contour data from FTM maps, either 1:500,000 scale (Agarwal et al. 2005, Gorenflo et al. In press) or 1:50,000 scale (McConnell et al. 2004) (Table 1). Again, the confirmation of the relationship between deforestation and topography lends confidence to the robustness of the relationship. The findings also provide some nuance to the understanding of the dynamics of the population-pressure variable; they quantify the easily observed pattern of settlement along perennial watercourses, which are by definition at lower local elevations.

Further experimentation with other topographic variables has yielded mixed results in explaining land-use. Nambena (2003) used higher order topographic variables (relief form and hillside exposures) derived from a digital elevation model to explain the distribution of intensive garden plots (tanimboly) in a study area in a mountainous region in eastern Madagascar. However, in the highlands, Barrett et al. (2004) were unable to detect a relationship between a plot's location in the topo-sequence and the benefits of SRI adoption.

Some studies have addressed the related issue of soil fertility. For example, Barrett et al. (2004) detected a significant effect of a binary soil quality variable on the benefits of SRI adoption. Other studies have provided detailed descriptions of farmers' responses to declining soil fertility resulting from swidden farming (Kramer et al. 1995, 1997, Brand and Pfund 1998, Messerli 2000, Nambena 2003, Carrière et al. 2005, Vågen 2006, Vågen et al. 2006a, 2006b, Styger et al. 2007). Such studies provide strong foundations for the incorporation of these processes in future models.
Weather conditions, and other biophysical factors, occasionally appear as explanatory factors in quantitative studies, but meteorological data are spatially and temporally sparse in Madagascar. To date, these factors have been treated through regional dummy variables (Barrett et al. 2004, Gorenflo et al. In press), or as qualitative, contextual factors (Kull 1998, Elmqvist et al. 2007). Improved treatment of such processes will be crucial to the development of improved models of human agency.

\section{CONCLUSIONS AND RECOMMENDATIONS}

The first decade of the new millennium has produced a suite of spatially explicit models of human agency in land change in Madagascar that have tested the findings of the landmark work of Green and Sussman (1990). These models have quantified the population-deforestation relationship - not as a goal, but as a step toward greater understanding of the role of human agency in land change. Clearly human presence must be accounted for in order to begin examining how those people came to be there, how and why they used the land once they arrived, and how that land-use might be shaped by public policy aimed at balancing their welfare with the conservation of the island's precious biodiversity. The increased sophistication of the models has come at no small cost in data collection and analysis, and we have to ask if these efforts have lived up to their promise of better judging the effects of policy actions aimed at conservation and improved human welfare.

This review suggests that a positive, albeit modest, response may be warranted. The models have begun to detect the 'signal' of policy impacts against the 'background' of what might have been expected in the absence of such policy (Ferraro and Pattanayak 2006). By first accounting for the effects of settlement location and topography, two spatially explicit models (McConnell et al. 2004, Gorenflo et al. In press) suggest that deforestation has been slower in protected areas than might otherwise have been expected, given trends in similar areas. of course, such tests of effectiveness are imperfect, as no true control group exists to definitively show what would have happened in the absence of such protection. The spatially explicit models have yet to address the implications of these policies for human welfare, especially the local populations directly affected.

LIMITATIONS OF THE CURRENT SET OF MODELS

The findings synthesized here are limited in their representation of the vast extent and diversity of the country and its people. The models reviewed concentrated on swidden systems associated with deforestation and on irrigated rice production, largely ignoring other aspects of the island's mix of agro-sylvopastoral land-uses. Livestock production, for example, has tended to appear in the econometric models as an explanatory variable impacting the land-use activity of interest - irrigated rice production. However, such an approach assumes that these practices are analytically separable when, in fact, the two are outcomes of the same decision-making process.

An important land-use dynamic that deserves further attention in spatially explicit models is the reforestation of the island's central highlands. Although several studies have documented increases in tree cover in various parts of the island (Rakoto Ramiarantsoa 1995, Kull 1998, Elmqvist et al. 2007), this outcome has rarely appeared as the dependent variable 
in spatially explicit models (cf. Vågen 2006). Interestingly, had the landmark Green and Sussman (1990) study not restricted its dependent variable to exclude all but humid forest, it might well have detected an increase in tree cover around the capital, thereby upsetting the neat relationship between population density and deforestation.

In addition, the studies reviewed here were conducted at quite different spatial scales (see Table 1), and we must be cognizant of the fact that relationships between land-change outcomes and various social and biophysical factors usually change with the scale of the analysis (Walsh et al. 1999, Kok et al. 2001, Veldkamp et al. 2001, Evans and Kelley 2004). The issue has been directly addressed in the case of Madagascar by Laney (2002, 2004), demonstrating how variables explaining land-use trajectories at farm level do not necessarily apply at village level, and arguing for close attention to such 'scalar dynamics.'

Finally, this review is limited in its temporal scope, neglecting most of the period of human habitation of the island. At the same time that scientists have been exploiting remote sensing to elucidate recent human-environment interactions in Madagascar, other researchers have been applying paleoecological tools to test long-held notions of the longer-term imprint of humans on the island's flora and fauna. The discovery of grass pollen and charcoal deposits in lake sediments predating the arrival of humans has undercut the conventional view holding people responsible for clearing large portions of the island's 'original' forest cover (Burney 1987a, 1987b, 1997, Gasse and Van Campo 1998, 2001, Burney et al. 2004). These findings are reinforced by botanical work demonstrating that the grasslands of Madagascar's central highlands are quite ancient, easily predating human settlement (Bond et al. 2008). Other anthropological work has attempted to parse the role of direct and indirect human impacts (i.e. hunting and habitat change, respectively) in the extinction / extirpation of non-human primates in late pre-historical Madagascar (Godfrey and Irwin 2007). The extension of land-use models back in time offers promise of understanding the legacies of these prior land-use dynamics. This is important because the projections of land-use models are often limited by non-stationarity; that is, the processes responsible for land change vary through time, such that variables assume different explanatory power in different time periods (Aspinall 2004).

RECOMMENDATIONS A number of recommendations emerge from this review of the existing set of spatially explicit land-use models, and from the broader literature on land-use in Madagascar.

Accounting for the presence of the human population will continue to be a sine qua non for land-use models, and the development of more reliable demographic data for Madagascar is imperative. Particularly urgent for broader scale studies are the reconciliation of the 1966 and 1993 population data, and the development of reliable data for preceding and intermediate periods. At finer scales, future models should be explicit about what land base is being considered in the analysis of demographic processes - whether it includes land currently under production only or also fallow land and / or 'virgin' land (i.e. effective population density). The consideration of land pressure in swidden systems can usefully be based on the frequency with which parcels are cropped (i.e. R-value), and a family's land endowment should be considered in the context of the number of people that land is expected to support and the proportion of them able to actively participate in farming (i.e. the dependency ratio).

To the degree that land-use models are aimed at contributing to improved policies, though, it is essential that they take into account the cultural, social, and political factors most amenable to policy, particularly those governing access to land, including both formal and informal arrangements for loan, rental, sharecropping, etc. The variety of institutions operating at different scales and through time poses a serious challenge, but it is not insurmountable. Future studies should avail themselves of tools that facilitate the systematic analysis of issues such as land tenure and the management of common-property resources, such as the IFRI protocols.

Relatively recent developments in agent-based, or multi-agent system, models that accommodate the behavior of individuals and groups (e.g. families, villages, state agencies) (e.g. Parker etal. 2003) could be helpful. Although nota land-use model, a useful example for Madagascar is Andriamasinoro and Angel's (2007) simulation of the artisanal mining of ultrapure quartz. The authors use a set of agents (local quartz buyers, conveyors, community, and state) who interact in an environment that includes the quartz lode, collection and grinding locations, and the export ports.

A reliable multi-temporal database of the country's roads must be developed for accurate assessment of the role of transportation infrastructure, one of the most important government interventions, on human agency in land change. The necessary information on the nominal state of infrastructure is held in FTM's archives, but considerable investment will be required to put that information into digital formats required for spatially explicit modeling.

Better data on land-use and land cover at different points in time is absolutely indispensable. Efforts to catalogue and make available all existing satellite imagery should be bolstered, and the development of well-documented land-use and land cover data from the country's significant aerial photography archive should be a high priority. Soil fertility and climatic factors could also offer improved explanation, perhaps building on the 1:200,000 Carte des ressources en eaux series developed by the Centre National de Recherche sur l'Environnement. However, the costs of developing appropriate soils data will not be negligible, as soil conditions tend to be quite heterogeneous, requiring intensive (and therefore costly) ground collection to appropriately capture meaningful variation.

While the past decade has seen significant progress in modeling land-use in Madagascar, the contributions to improved policy have been modest. Demonstrating the effectiveness of conservation policy (i.e. protected areas) is crucial to securing and effectively using scarce financial resources. Parsing the effects of different forms of protection (e.g. National Park or special Reserve) will provide even better guidance. A crucial area for improvement is in assessing the human welfare impacts of conservation policy. Many of the econometric models discussed above set out specifically to examine these issues, and the integration of spatially explicit and econometric approaches is desirable. Caution must be exercised, however, to ensure that the models do not become so complex that their methods are inaccessible to policy makers and stakeholders. 
The sorts of improvements outlined above may enable future models to better contribute to the formulation of policy that can balance protection of the island's biodiversity with securing the livelihoods of the Malagasy people. However, until such time as verification and validation of model results are achieved, the model outputs should be treated with caution. A model inter-comparison effort involving scientists, policy makers and stakeholders would be extremely valuable in ensuring that future modeling efforts provide results that are reliable, robust and relevant.

\section{POSTSCRIPT}

Since this manuscript was initially submitted, news reports have cited the Ravalomanana government's negotiations to lease large tracts of farmland to Daewoo as a cause célèbre in the political turmoil in early 2009.

\section{ACKNOWLEDGMENTS}

This work was made possible by the support of the Office of the Provost at Michigan State University to the Center for Systems Integration and Sustainability. Very helpful comments were provided by Vanessa Hull, James Millington, Nils Peterson, Andres Vina, and anonymous reviewers. It is enormously valuable to have the benefit of comments and suggestions by reviewers who are familiar with Madagascar; this attests to the importance of a journal dedicated to this topic. While every effort has been made to fairly represent the work of the colleagues whose studies are the subject of this review, it is inevitable that some aspects of those studies have been omitted or misinterpreted. These authors are enjoined to engage the author and one another in hopes of advancing the praxis, and delivering on the promise of modeling human agency in land-use in Madagascar.

\section{REFERENCES}

Agarwal, D. K., Silander, J. A., Gelfand, A. E., Dewar, R. E. and Mickelson Jr., J. G. 2005. Tropical deforestation in Madagascar: Analysis using hierarchical spatially explicit, Bayesian regression models. Ecological Modelling 185, 1: 105-131. (doi:10.1016/j.ecolmodel.2004.11.023)

Agrawal, A. 2002. Common resources and institutional sustainability. In: The Drama of the Commons. E. Ostrom., T. Dietz, N. Dolšak, P. C. Stern, S. C. Stonich and J. Weber (eds.), pp 41-86. National Academies Press, Washington, D. C.Andriamasinoro, F. and Angel, J.-M. 2007. Modeling the ultra-pure quartz exploitation in northeastern Madagascar: Impact of the activity on the socio-economical situation of the population. Journal of Socio-Economics 36, 2: 311-329. (doi:10.1016/ j.socec.2005.11.035)

Andriamialisoa, F. and Langrand, O. 2003. The history of zoological exploration of Madagascar. In: The Natural History of Madagascar. S. M. Goodman and J. P. Benstead (eds.), pp 1-15. University of Chicago Press, Chicago.Antona, M., Bienabe, E. M., Salles, J. M., Pechard, G., Aubert, S. and Ratsimbarison, R. 2004. Rights transfers in Madagascar biodiversity policies: Achievements and significance. Environment and Development Economics 9: 825-847. (doi:10.1017/S1355770X04001640)

Aspinall, R. J. 2004. Modelling land use change with generalized linear and generalized additive models - a multi-model analysis of change between 1860 and 2000 in Gallatin Valley, Montana. Journal of Environmental Management, 72, 1-2: 91-103. (doi:10.1016/ j.jenvman.2004.02.009)

Association des Géographes de Madagascar. 1969. Atlas de Madagascar. Bureau pour le Développement de la Production Agricole, Tananarive.

Barrett, C. B. and Dorosh, P. A. 1996. Farmers' welfare and changing food prices: Nonparametric evidence from rice in Madagascar. American Journal of Agricultural Economics 78, 3: 656-669.
Barrett, C. B., Moser, C. M., McHugh, O. V. and Barison, J. 2004. Better technology, better plots, or better farmers? Identifying changes in productivity and risk among Malagasy rice farmers. American Journal of Agricultural Economics 86, 4: 869-888.

Bellemare, M. F. and Barrett, C. B. 2003. An Asset Risk Theory of Share Tenancy. Working Paper 03-17. Department of Applied Economics and Management, Cornell University, Ithaca, New York.

Bernier, R. and Dorosh, P. A. 1993. Constraints on Rice Production in Madagascar: The Farmerıs Perspective. Working Paper 34. Cornell Food and Nutrition Policy Program, Cornell University, Ithaca, New York.

Blanc-Pamard, C. \& Cambrézy, L. (eds.) 1995. Terre, Terroir, Territoire: Les Tensions Foncières. Éditions ORSTOM, Paris

Bloch, M. 1984. Property and the end of affinity. In: Marxist Analyses and Social Anthropology. M. Bloch (ed.), pp 203-228. Tavistock Publications, New York.Bloch, M. 1995. People into places: Zafimaniry concepts of clarity. In: The Anthropology of Landscape: Perspectives on Place and Space. E. Hirsch and M. O'Hanlon (eds.), pp 63-77. Oxford University Press, Oxford, U. K.

Bond, W., Silander Jr., J. A., Ranaivonasy, J. and Ratsirarson, J. 2008. The antiquity of Madagascar's grasslands and the rise of $\mathrm{C}_{4}$ grassy biomes. Journal of Biogeography 35, 10: 1743-1758. (doi:10.1111/j.13652699.2008.01923.x)

Boserup, E. 1965. The Conditions of Agricultural Growth: The Economics of Agrarian Change under Population Pressure. Allen and Unwin, London.

Boserup, E. 1970. Woman's Role in Economic Development. Allen and Unwin, London.Brand, J. and Pfund, J. L. 1998. Site- and watershed-level assessment of nutrient dynamics under shifting cultivation in eastern Madagascar. Agriculture, Ecosystems and Environment 71, 1-3: 169183. (doi:10.1016/S0167-8809(98)00139-X)

Burney, D. A. 1987a. Late Holocene vegetational change in central Madagascar. Quaternary Research 28, 1: 130-143.

Burney, D. A. 1987b. Late quaternary stratigraphic charcoal records from Madagascar. Quaternary Research 28, 2: 274-280.

Burney, D. A. 1997. Theories and facts on Holocene environmental change before and after human colonization. In: Natural Change and Human Impact in Madagascar. S. M. Goodman and B. D. Patterson (eds.), pp 75-89. Smithsonian Institution Press, Washington, D. C.

Burney, D. A., Burney, L. P., Godfrey, L. R., Jungers, W. L., Goodman, S. M., Wright H. T. and Jull, A. J. T. 2004. A chronology for late prehistoric Madagascar. Journal of Human Evolution 47, 1-2: 25-63. (doi:10.1016/ j.jhevol.2004.05.005)

Carrière, S. M., Andrianotahiananahary, H., Ranaivoarivelo, N. \& Randriamalala, J. 2005. Savoirs et usages des recrus post-agricoles du pays Betsileo: valorisation d`une biodiversité oubliée à Madagascar. vertigo 6, 1: 1-14.

Casse, T., Milhøj, A., Ranaivoson, S. and Randriamanarivo, J. R. 2004. Causes of deforestation in southwestern Madagascar: What do we know? Forest Policy and Economics 6, 1: 33-48. (doi:10.1016/S13899341(02)00084-9)

Chowdhury, R. R. and Turner II, B. L. 2006. Reconciling agency and structure in empirical analysis: Smallholder land use in the southern Yucatan, Mexico. Annals of the Association of American Geographers 96, 2: 303-322. (doi:10.1111/j.1467-8306.2006.00479.x)

Coulaud, D. 1973. Les Zafimaniry. Un Groupe Ethnique de Madagascar à la Poursuite de la Forêt. Fanotamboky Malagasy, Antananarivo.

de Flacourt, E. 1661. Histoire de la Grande Isle Madagascar avec une Relacion de ce qui sıest passé en Années 1655, 1656, \& 1657, non encore vue par la Première. Pierre Bien-fait, Paris.

Deichmann, U. 1994. A Medium Resolution Population Database for Africa. Database Documentation and Digital Database. National Center for Geographic Information and Analysis. University of California, Santa Barbara, California.

Direction des Eaux et Forêts, Deutsche Forstservice GmbH, Entreprise d’Etudes de Développement Rural "Mamokatra" and FoibenTaosarintanin'I Madagasikara. 1996. In Phase 1, Direction des Eaux et Forêts, République de Madagascar: Inventaire écologique forestier national: situation de départ, résultats, analyses et recommendations. Ministère de I'Environnement, Plan d'Actions Environnementales, Programme Environnemental. 
Durbin, J., Bernard, K. and Fenn, M. 2003. The role of socioeconomic factors in loss of Malagasy biodiveristy. In: The Natural History of Madagascar. S. M. Goodman and J. P. Benstead (eds.), pp 142-146. The University of Chicago Press, Chicago

Elmqvist, T., Pyykönen, M., Tengö, M., Rakotondrasoa, F., Rabakonandrianina, E. and Radimilahy, C. 2007. Patterns of loss and regeneration of tropical dry forest in Madagascar: The social institutional context. PLOS ONE 2, 5: e402. (doi:10.1371/journal.pone.0000402)

Evans, T. P. and Kelley, H. 2004. Multi-scale analysis of a household level agent-based model of landcover change. Journal of Environmental Management 72, 1-2: 57-72. (doi:10.1016/j.jenvman.2004.02.008)

Fafchamps, M. and Minten, B. 2002. Returns to social network capital among traders. Oxford Economic Papers 54: 173-206

Fafchamps, M. and Moser, C. 2003. Crime, isolation and law enforcement. Journal of African Economies 12: 625-671.

Ferraro, P. J. and Pattanayak, S. K. 2006. Money for nothing? A call for empirical evaluation of biodiversity conservation investments. Plos Biology 4, 4: e105. (doi:10.1371/journal.pbio.0040105)

Gasse, F. and Van Campo, E. 1998. A 40,000-yr pollen and diatom record from Lake Tritrivakely, Madagascar, in the southern tropics. Quaternary Research 49, 3: 299-311. (doi:10.1006/qres.1998.1967)

Gasse, F. and Van Campo, E. 2001. Late Quaternary environmental changes from a pollen and diatom record in the southern tropics (Lake Tritrivakely, Madagascar). Palaeogeography Palaeoclimatology Palaeoecology 167, 3-4: 287-308. (doi:10.1016/S0031-0182(00)00242-X)

Geertz, C. 1963. Agricultural Involution: The Process of Ecological Change in Indonesia. Association of Asian Studies, University of California Press, Los Angeles.

Geist, H. J. and Lambin, E. F. 2001. What Drives Tropical Deforestation? A Meta-Analysis of Proximate and Underlying Causes of Deforestation Based on Subnational Case Study Evidence. LUCC Report Series No. 4. LUCC International Project Office, University of Louvain, Belgium.

Geist, H. J. and Lambin, E. F. 2002. Proximate causes and underlying driving forces of tropical deforestation. Bioscience 52, 2: 143-150. (doi:10.1641/0006-3568(2002)052[0143:PCAUDF]2.0.CO;2)

Geist, H. J. and Lambin, E. F. 2004. Dynamic causal patterns of desertification. Bioscience 54, 9: 817-829. (doi:10.1641/0006-3568(2004)054[0817: DCPOD]2.0.CO;2)

Godfrey, L. R. and Irwin, M. T. 2007. The evolution of extinction risk: Past and present anthropogenic impacts on the primate communities of Madagascar. Folia Primatologica 78: 405-419. (doi:10.1159/000105152)

Gorenflo, L. J., Corson, C., Chomitz, K. M., Harper, G., Honzák, M. and Özler, B. In press. Exploring the relationship between people and deforestation in Madagascar. In: Human Population: The Demography and Geography of Homo sapiens and their Implications for Biodiversity. R. Cincotta and L. J. Gorenflo (eds.). Springer, Berlin.

Green, G. M. and Sussman, R. W. 1990. Deforestation history of the eastern rainforests of Madagascar from satellite images. Science 248, 4952: 212-215. (doi:10.1126/science.248.4952.212)

Gutman, G., Janetos, A. C., Justice, C. O., Moran E. F., Mustard, J.F., Rindfuss, R. R., Skole, D., Turner II, B. L. and Cochrane, M. A. (eds.) 2004. Land Change Science: Observing, Monitoring and Understanding Trajectories of Change on the Earth's Surface. Remote Sensing and Digital Image Processing series, vol. 6. Kluwer Academic Publishers, Dordrecht, The Netherlands.

Horning, N. R. 2000. Explaining Compliance with Rules Governing Common-Pool Forest Resources Use and Conservation: Dynamics in Bara Country, Southwestern Madagascar. Presented at the Eighth Conference of the International Association for the Study of Common Property, Indiana University, Bloomington.

Jacoby, H. G. and Minten, B. 2008. On Measuring the Benefits of Lower Transport Costs. Policy Research Working Paper Series, No. 4484. The World Bank, Washington, D. C.

Jarosz, L. 1993. Defining and explaining tropical deforestation: Shifting cultivation and population growth in colonial Madagascar (1896-1940). Economic Geography 69, 4: 366-379.

Jarosz, L. 1996. Defining deforestation in Madagascar. In: Liberation Ecologies: Environment, Development, Social Movements. R. Peet and M. Watts (eds.), pp 148-164. Routledge, New York.
Kaimowitz, D. 1997. Factors determining low deforestation: The Bolivian Amazon. Ambio 26, 8: 537-540.

Kaimowitz, D. and Angelsen, A. 1998. Economic Models of Tropical Deforestation: A Review. Centre for International Forestry Research, Bogor, Indonesia.Karaska, G., Andriamananjara, R. and W. McConnell. 1996. The Regional Structure of Third World Economies: Rural-Urban Dynamics in Kenya and Madagascar. Clark University and the Institute of Madagascar for Techniques of Planning, Worcester, M. A

Keck, A., Sharma, N. P. and Feder, G. 1994. Population Growth, Shifting Cultivation, and Unsustainable Agricultural Development: A Case Study in Madagascar, World Bank Discussion Paper No. 234. The World Bank, Washington, D. C.Keys, E. and McConnell, W. J. 2005 Global change and the intensification of agriculture in the tropics. Global Environmental Change 15, 4: 320-337. (doi:10.1016/ j.gloenvcha.2005.04.004)

Kok, K., Farrow, A., Veldkamp, A. and Verburg P. H. 2001. A method and application of multi-scale validation in spatial land use models. Agriculture Ecosystems \& Environment 85, 1-3: 223-238. (doi:10.1016/S01678809(01)00186-4)

Kottak, C. P. 1980. The Past in the Present: History, Ecology, and Cultural Variation in Highland Madagascar. University of Michigan Press, Ann Arbor.

Kramer, R. A., Sharma, N. P. and Munasinghe, M. 1995. Valuing Tropical Forests: Methodology and Case Study of Madagascar. World Bank Environment Paper No. 13. The World Bank, Washington, D. C.

Kramer, R. A., Richter, D. D., Pattanayak S. and Sharma, N. P. 1997 Ecological and economic analysis of watershed protection in eastern Madagascar. Journal of Environmental Management 49, 3: 277-295. (doi:10.1006/jema.1995.0085)

Kull, C. A. 1998. Leimavo revisited: Agrarian land-use change in the highlands of Madagascar. The Professional Geographer 50, 2: 163-176. (doi:10.1111/0033-0124.00112)

Kull, C. A. 2004. Isle of Fire: The Political Ecology of Landscape Burning in Madagascar. The University of Chicago Press, Chicago.

Kull, C. A. 2008. Saving land with a spades: Human landscape transformations in the central and southern highlands. In: Greening the Great Red Island: Madagascar in Nature and Culture. J. C. Kaufmann (ed.), pp 113-136. Africa Institute of South Africa, Pretoria.

Lambin, E. 2000. Land cover assessment and monitoring. In: Encyclopedia of Analytical Chemistry: Applications, Theory, and Instrumentation. R. A. Meyers (ed.), pp ??. Wiley, New York.

Lambin, E. and Geist, H. J. (eds.). 2006. Land-Use and Land-Cover Change: Local Processes, Global Impacts. Springer, Heidelberg, Germany.

Laney, R. M. 2002. Disaggregating induced intensification for land-change analysis: A case study from Madagascar. Annals of the Association of American Geographers 92, 4: 702-726.

Laney, R. M. 2004. A process-led approach to modeling land change in agricultural landscapes: A case study from Madagascar. Agriculture Ecosystems \& Environment 101, 2-3: 135-153. (doi:10.1016/j.agee.2003.09.004)

Le Bourdiec, F. 1974. Hommes et paysages du riz à Madagascar étude de géographie humaine. Laboratoire de Géographie de Tananarive, Madagascar. McConnell, W. 2001. Land use and cover change. In: The International Encyclopedia of the Social and Behavioral Sciences. N. Smelser and P. Bates (eds.), pp 8251-8255. Elsevier, Oxford, U. K.

McConnell, W. J. 2002. Misconstrued land use in Vohibazaha: Participatory planning in the periphery of Madagascar's Mantadia National Park. Land Use Policy 19, 3: 217-230. (doi:10.1016/S0264-8377(02)00016-9)

McConnell, W. J. and Sweeney, S. P. 2005. Challenges of forest governance in Madagascar. Geographical Journal 171, 3: 223-238. (doi:10.1111/j.14754959.2005.00162.x)

McConnell, W. J., Sweeney, S. P. and Mulley, B. 2004. Physical and social access to land: spatio-temporal patterns of agricultural expansion in Madagascar. Agriculture, Ecosystems \& Environment 101: 171-184.

Messerli, P. 2000. Use of sensitivity analysis to evaluate key factors for improving slash-and-burn cultivation systems on the eastern escarpment of Madagascar. Mountain Research and Development 20, 1: 32-41.

Millington, J. D. A., Perry, G. L. W. and Romero-Calcerrada, R. 2007. Regression techniques for examining land use/cover change: A case study of a Mediterranean landscape. Ecosystems 10, 4: 562-578. (doi:10.1007/s10021-007-9020-4) 
Mistiaen, J., Özler, B., Razafimanantena, T. and Razafindravonona, J. 2002. Putting Welfare on the Map in Madagascar. Africa Region Working Paper No. 34. The World Bank, Washington, D. C

Mladenoff, D. J. and Baker, W. L. 1999. Development of forest and landscape modeling approaches. In: Spatial Modeling of Forest Landscape Change: Approaches and Applications. D. J. Mladenoff and W. L. Baker (eds.), pp 1-13. Cambridge University Press, Cambridge, U. K.

Montagne, P. \& Bertrand, A. 2006. Histoire des politiques forestières au Niger, au Mali et à Madagascar. In: L’État et la Gestion Locale Durable des Forêts en Afrique Francophone et à Madagascar. A. Bertrand, P. Montagne \& A. Karsenty (eds.), pp 54-83. L’Harmattan, Paris.

Moser, C. M. and Barrett, C. B. 2006. The complex dynamics of smallholder technology adoption: The case of SRI in Madagascar. Agricultural Economics 35, 3: 373-388. (doi:10.1111/j.1574-0862.2006.00169.x)

Nambena, S. M. 2003. Using geographic information systems to assess possibilities of expanding traditional agroforestry in slash-and-burn zones in Madagascar. Mountain Research and Development 23, 4: 329-333. (doi:10.1659/0276-4741(2003)023[0329:UGISTA]2.0.CO;2)

Nelson, G. C. and Hellerstein, D. 1997. Do roads cause deforestation? Using satellite images in econometric analysis of land use. American Journal of Agricultural Economics 79, 1: 80-88.

Nelson, R. and Horning, N. 1993. AVHRR-LAC estimates of forest area in Madagascar, 1990. International Journal of Remote Sensing 14, 8: 1463 1475. (doi:10.1080/01431169308953981)

Norris, S. 2006. Madagascar defiant. Bioscience 56, 12: 960-965. (doi:10.1641/0006-3568(2006)56[960:MD]2.0.C0;2)

Ostrom, E. 1990. Governing the Commons: The Evolution of Institutions for Collective Action. Cambridge University Press, New York.

Ostrom, E. and Wertime, M. B. 2000. International foresty resources and institutions research strategy. In: People and Forests: Communities, Institutions, and Governance. C. C. Gibson, M. McKean and E. Ostrom (eds.), pp 243-268. MIT Press, Cambridge, M. A.

Ostrom, E., Dietz, T., Dolšak, N., Stern, P. C., Stonich, S. C. and Weber, J. (eds.). 2002. The Drama of the Commons. National Academies Press, Washington, D. C

Parker, D. C., Manson, S., Janssen, M. A., Hoffmann M. J. and Deadman, P. J. 2003. Multi-agent systems for the simulation of land-use and land-cover change: A review. Annals of the Association of American Geographers 93: 314-337.

Pavageau, J. 1981. Jeunes paysans sans terres, I'exemple malgache (une communauté villageoise en période révolutionnaire). Collection Alternatives Paysannes. L’Harmattan, Paris.

Pingali, P., Bigot, Y. and Binswanger, H. P. 1987. Agricultural Mechanization and the Evolution of Farming Systems in Sub-Saharan Africa. Johns Hopkins University Press for The World Bank, Baltimore, U. S. A.

Raik, D. 2007. Forest management in Madagascar: An historical overview. Madagascar Conservation \& Development 2, 1: 5-10.

Raison, J. P. 1970. Paysage rural et démographie. Leimavo (nord du pays Betsileo). Études Rurales 37-38-39: 345-377.

Rakoto Ramiarantsoa, H. 1995. Les boisements dieucalyptus dans I'est de I'Imerina (Madagascar): de I'appropriation foncière à la gestion paysanne. In: Terre, Terroir, Territoire: Les Tensions Foncières. C. BlancPamard and L. Cambrézy (eds.), pp 83-103. Éditions ORSTOM, Paris.

Randrianarisoa, J. C. and Minten, B. 2001. Agricultural Production, Agricultural Land and Rural Poverty in Madagascar. Working Paper 112. Cornell Food and Nutrition Policy Program, Cornell University, Ithaca, New York.
Rudel, T. K. 2005. Tropical Forests: Regional Paths of Destruction and Regeneration in the Late Twentieth Century. Columbia University Press, New York.

Ruthenberg, H. 1976. Farming Systems in the Tropics, 2nd ed. Oxford University Press, Oxford, UK.

Schoonmaker Freudenberger, K. 1995. Tree and Land Tenure: Using Rapid Appraisal to Study Natural Resource Management: A Case Study from Anivorano, Madagascar. Community Forestry Case Study 10. Food and Agriculture Organization of the United Nations, Rome.

Skole, D. and Cochrane, M. A. 2004. Observations of LCLUC in regional case studies. In: Land Change Science: Observing, Monitoring and Understanding Trajectories of Change on the Earth's Surface. G. Gutman, A. C. Janetos, C. O. Justice, E. F. Moran, J. F. Mustard, R. R. Rindfuss, D. Skole, B. L. Turner II, and M. A. Cochrane (eds.), pp 53-55. Kluwer Academic Publishers, Dordrecht, The Netherlands.

Styger, E., Rakotondramasy, H. M., Pfeffer, M. J., Fernandes, E. C. M. and Bates, D. M. 2007. Influence of slash-and-burn farming practices on fallow succession and land degradation in the rainforest region of Madagascar. Agriculture, Ecosystems \& Environment 119, 3-4: 257-269. (doi:10.1016/j.agee.2006.07.012)

Turner II, B. L., Lambin, E. F. and Reenberg, A. 2007. The emergence of land change science for global environmental change and sustainability. Proceedings of the National Academy of Sciences of the United States of America 104, 52: 20666-20671. (doi:10.1073/pnas.0704119104)

Vågen, T.-G. 2006. Remote sensing of complex land use change trajectories: A case study from the highlands of Madagascar. Agriculture, Ecosystems \& Environment 115, 1-4: 219-228. (doi:10.1016/ j.agee.2006.01.007)

Vågen, T.-G., Andrianorofanomezana, M.-A. A. and Andrianorofanomezana, S. 2006a. Deforestation and cultivation effects on characteristics of oxisols in the highlands of Madagascar. Geoderma 131, 1-2: 190-200. (doi:10.1016/j.geoderma.2005.03.026)

Vågen, T.-G., Walsh, M. G. and Shepherd, K. D. 2006b. Stable isotopes for characterisation of trends in soil carbon following deforestation and land use change in the highlands of Madagascar. Geoderma 135: 133 139. (doi:10.1016/j.geoderma.2005.11.012)

Veldkamp, A., Verburg, P. H., Kok, K., de Koning, G. H. J., Priess, J. and Bergsma, A. R. 2001. The need for scale sensitive approaches in spatially explicit land use change modeling. Environmental Modeling and Assessment 6, 2: 111-121. (doi:10.1023/A:1011572301150)

Vérin, P. 1992. Socio Economic Factors in Economic Development in Madagascar. In: Final Report for USAID Madagascar.

Wade, R. 1994. Village Republics: Economic Conditions for Collective Actions in South India. ICS Press, San Francisco.

Walker, R. and Solecki, W. 2004. Theorizing land-cover and land-use change: The case of the Florida Everglades and its degradation. Annals of the Association of American Geographers 94, 2: 311-328.

Walsh, S. J., Evans, T. P., Welsh, W. F., Entwisle, B. and Rindfuss, R. R. 1999. Scale-dependent relationships between population and environment in northeastern Thailand. Photogrammetric Engineering \& Remote sensing 65, 1: 97-105

Walt, V. 2008. The breadbasket of South Korea: Madagascar. TIME, Sunday, Nov. 23. Available at <http://www.time.com/time/world/article/0,8599,1861145,00.html>.

\section{EDITORIAL NOTE}

The recent political instability in Madagascar is having far-reaching consequences beyond the social and cultural aspects. Due to an imminent lack of governance and responsibility, several protected areas, such as Masoala and Marojejy National Parks, have been targeted by increased illegal logging and pillaging of other natural resources including rare and endemic plant and animal species for export to other countries. This has been reported by several national and international news press and other medias. For more details please refer to http://www.lllegal-logging.info/item_single. php? item=news\&item_id=3247\&approach_id=18 